\title{
Increased The Adolescent Self-Identity Using The Peplau-Erickson-Stuart
} Model

\author{
Eni Hidayati1, Novy Helena Catharina. Daulima², Ice Yulia Wardani²
}

${ }^{1}$ University of Muhammadiyah Semarang, Indonesia

2 University of Indonesia, Indonesia

\section{Article Info}

Article History:
Accepted December 28th,
2019

Keywords:

Adolescent; Therapeutic group therapy; Family psychoeducation

\begin{abstract}
Without proper stimulation, self-identity formation in adolescents may lead to inferiority, and further to the mental health problem. It is important to give positive stimulation for adolescents and psychoeducation for the family properly and effectively to improve adolescence identity development. As we know, adolescence is a period of age which is considered to be problematic and crucial for them to set their remarkable foundation regarding the interaction with the surrounding people and environment. This research was aimed to find out the result of therapeutic group therapy for adolescent and family psychoeducation toward the improvement of adolescence development. A case report was used as the method of the research, in which 5 clients were given health education care according to the problem faced by the family during the adolescence development stimulation. The special therapy given was the adolescence therapeutic group therapy and family psychoeducation. The result of therapeutic group therapy is the ability to improve family and adolescence self-identity development within the 10 aspects of adolescence stage; biological, psychosexual, cognitive, language, moral, spiritual, emotional, psychosocial, talent, and creativity. The result of the research was expected to be an input for the Department of Health, especially for the administrator of the community health program in dealing with adolescence mental problems. The research is also expected to be the evidence-based practice in the community of mental health nursing.
\end{abstract}

\section{INTRODUCTION}

Mental health is welfare represented by happiness, balance, satisfaction, selfachievement, and optimism. Mental health can also be described as having a positive attitude, improvement, development, selfactualization, unity, freedom, and also own the convenient perception between reality and the ability to adapt to the surrounding environment. ${ }^{1}$ Mental health is also a condition where an individual realizes his or her ability, able to control stress, and productively works and gives a contribution to society. Therefore, it can be concluded that mental health is referred to welfare where an individual realizes his or her ability, able to relieve stress, has the suitable perception between reality and the ability for the adaptation with the surrounding environment, owns selfactualization, and able to productively

Corresponding author:

Eni Hidayati

enihidayati@unimus.ac.id

South East Asia Nursing Research, Vol 1 No 3, December 2019

ISSN:2685-032X

DOI: https://doi.org/10.26714/seanr.1.3.2019.128-136 
works and gives a contribution to the society. ${ }^{2}$

Improvement and development simultaneously happen in our life. The development is accomplished according to the pattern of each development stage which is also the result of the previous development stage and the requirement for the next stage. Adolescence is a crucial stage in which adolescent starts to form selfidentity, independence, and eager to be involved in a mission. ${ }^{3}$ Some factors affect adolescence mental health is biological, psychological, and sociocultural factors. Besides, health, environment, and individual attitude are also the supporting factors which influence adolescence mental health development. The environment means family, school, and peer group for the adolescence. In this case, the government has been facilitated by adolescence development by providing non-formal health care. It is done by giving optimum guidance to adolescents' intellectual development and stimulating adolescents' creative thinking and problem-solving ability.

The nursing care is given to the self-identity formation, either the professional or specialist nurse was given using Peplau's interpersonal model. It is possible since the self-identity formation in adolescents may be reoccurred as they did not feel comfortable during the nursing caregiving process. According to Peplau (1991), a nurse should have the value, uniqueness, art, and nursing science-based interpersonal relationship in delivering the health practice. Those aspects help nurses to build a therapeutic relationship with the adolescent. Peplau (1991)stated that the therapeutic relationship will achieve the goals when the nurse accomplished 4 stages of the relationship, which are orientation, identification, exploitation, and resolution. ${ }^{3}$

The therapy given by a nurse for the family is family therapy, group therapy, psychoeducation therapy, supportive therapy, self-assistance therapy, and therapeutic group therapy. ${ }^{4}$ On the other hand, the most suitable therapy for the adolescence development stage is group therapy and environmental therapy. One of the therapy techniques used to optimize adolescence development is therapeutic group therapy (TGT). It is a group therapy that enables the members to share their experiences, to help each other, and to find problem solving and anticipation, by giving an effective way to control stress. ${ }^{5}$ TGT is aimed to defend the homeostasis on either the possible spontaneous changes or continuous event. TGT helps the member to prevent health problems, training and developing group member potency, and also improve member's self-quality in order to be able in solving any problems of life. ${ }^{6}$ This therapy is given to all the age levels based on its development stage. It can also be done in a group and individually by stimulating development and improvement.

One of the research about adolescence selfidentity was showed about the identity achievement status, as the subject taken was the college students who are in the last stage of adolescence age. ${ }^{7}$ On the other hand, other research showed that therapeutic group therapy significantly improved the family's cognitive and psychometric ability in stimulating children's development. ${ }^{8}$ It improved the cognitive and psychometric ability at $45.5 \%$ from the initial $38.5 \%$. The other study stated that self-improvement and selfidentity are significantly improved after therapeutic group therapy. ${ }^{9}$ On the other hand, the other group which was not given the same treatment could not show any significant improvement. Adolescence is a crucial stage for problems and to form a solid basis for the internal competence which enables an individual to adapt and interact with the surrounding environment. ${ }^{6}$

The nursing care for the adolescents in this study used Peplau interpersonal relationship approach and the development 
theory from Erickson. The theory stated that a therapeutic relationship as the interpersonal process which involved nurse and client communicative interaction in order to identify and solve the client's problem. During the therapeutic relationship, it is suggested that the nurse employs his or her self as the instrument to defend and build the relationship with the client. This way, it is expected for the client to be able to deliver all of his or her feelings and the nurse can further draw the solution in the following nursing care. In applying the interpersonal relationship to the client, the nurse as an outsider carried the orientation and identification stage during the adolescence analysis. After the analysis, the nurse carried the exploitation stage, which was the nursing care practice. After that, the resolution stage was applied using the interpersonal relationship theory of Peplau during the evaluation of the nursing care applied.

\section{METHODS}

The nursing care applied was using the case report model. It was a detail report about signs, symptoms, diagnosis, treatment, and also the follow up on a client. It is usually applied for an unusual or new event either on a group or individual client. The case report in this study reported the case on the client from RW 04 Mulyaharja with the adolescence self-identity therapy by the specialist nurse as explained in table 1 . The intervention plot was in accordance with the interpersonal theory of Peplau and the theory of Erickson started from the analysis, nursing diagnosis, nursing care practice and nursing care practice result, client's support system, and also the difference after the application of the intervention. The data gained was primary data from scanning format and evaluation instrument (prepost) on the adolescent self-identity diagnosis. There were 5 healthy adolescents taken as clients. All of the clients were finished with specialist nursing care practice, therapeutic group therapy, and family psychoeducation.

\section{RESULTS}

From table 1, we can see that in the physical and psychosocial aspect, the average improvement was mainly on the weight gain aspect from $60 \%$ to $100 \%$, with the overall average $80 \%$ to $100 \%$. Besides, for the cognitive and linguistic aspect, the highest improvement was on able to suspect with the improvement from $60 \%$ to $100 \%$, with the overall improvement of $84.61 \%$ to $98.46 \%$. For the moral and spiritual aspect, we can see the understanding of the ethical value, religious and social value of $80 \%$ to $100 \%$ with the overall value was from $85.71 \%$ to $100 \%$. From the emotional and psychosocial aspect, we can see the improvement in able to not forcing the parents to follow their demand from $60 \%$ to $100 \%$, with the average value of $83.33 \%$ to $96.66 \%$. From talent and creativity, the significant improvement was on the ability in delivering questions and opinions from $60 \%$ to $100 \%$, with the overall value of $65.71 \%$ to $94.28 \%$. It can be concluded that the biggest deviation was on the emotional and psychosocial aspects with $14.29 \%$.

First, the clients were given specialist nursing practice which was consisted of 5 sessions. The first session, identify the personal problem faced by the caregiver or the parents with the adolescent in the family. In the second session, the method of stimulating adolescence improvement was explained. After that, stress management was carried in the third session. Burden's management was carried on the fourth session, and the use of the supportive family system in the fifth session.

From table 2, we are able to see the characteristic, predisposition factor, and the precipitation factor of the five clients. Client Ms. S owned the ability of Female, 14 years old, second grade of junior high school, parents are labors whose income below the provincial minimum wage, having 5 siblings. Ms. S is healthy, without any serious disease history, normal eating pattern, the weight gain in accordance to 
the development, client is able to deliver her opinion, able to critically speak about problem, able to differentiate which is good and bad, loves to try new thing, has many friends, able to adapt in the new environment, extrovert, cheerful, involve in some social activities.

The following (Table 3) is the explanation about the ability of adolescence self-identity formation from the development task before and after the intervention of therapeutic group therapy and family psychoeducation.

Table 3 explained about adolescence selfidentity ability involved: able to objectively assess himself/herself at $80 \%$ which represents $100 \%$ improvement. The achievement in the self-identity formation stage depends on the problem-solving process in the previous stage. If an adolescent failed in the previous development task, the result may influence the following stage. The next, about the ability to figure in the future, was improved from $60 \%$ to $100 \%$. The ability to make a decision was improved from $60 \%$ to $100 \%$. The love of the individual self-was improved from $40 \%$ to $100 \%$. The ability to interact with others was improved from $80 \%$ to $100 \%$. The responsibility was improved from $60 \%$ to $80 \%$. Adolescents started to represent their independence by $100 \%$. And they were able to solve the problem with assistance was improved from $80 \%$ to $100 \%$.

Table 1

TGT Effectiveness toward self-identity achievement on adolescent in RW 4 Mulyaharja District

\begin{tabular}{|c|c|c|c|c|c|}
\hline \multirow[t]{2}{*}{ No } & \multirow[t]{2}{*}{ Adolescence Change } & \multicolumn{2}{|c|}{ Pre } & \multicolumn{2}{|c|}{ Post } \\
\hline & & $\begin{array}{l}\text { Number } \\
\text { of clients }\end{array}$ & $\%$ & $\begin{array}{l}\text { Number } \\
\text { of clients }\end{array}$ & $\%$ \\
\hline \multirow[t]{8}{*}{1} & Physical \& Psychosexual Aspect & & & & \\
\hline & a. The appearance of puberty signs & 4 & 80 & 5 & 100 \\
\hline & b. Weight gain & 3 & 60 & 5 & 100 \\
\hline & c. Height improvement & 4 & 80 & 5 & 100 \\
\hline & d. Interest to sex opposite & 4 & 80 & 5 & 100 \\
\hline & e. Improved sexual fantasy and imagination & 4 & 80 & 5 & 100 \\
\hline & f. Improved self-interest & 5 & 100 & 5 & 100 \\
\hline & Average & 4 & 80 & 5 & 100 \\
\hline \multirow[t]{15}{*}{2} & The cognitive and linguistic aspect & & & & \\
\hline & a. Able to think about the causative effect & 3 & 60 & 5 & 100 \\
\hline & b. Able to suspect & 4 & 80 & 5 & 100 \\
\hline & c. Able to decide & 4 & 80 & 5 & 100 \\
\hline & d. Able to gather idea, thinking, and concept & 4 & 80 & 5 & 100 \\
\hline & e. Able to analyze & 4 & 80 & 4 & 80 \\
\hline & f. The change in people perception & 5 & 100 & 5 & 100 \\
\hline & g. Able to understand others & 4 & 80 & 5 & 100 \\
\hline & h. Able to think systematically & 5 & 100 & 5 & 100 \\
\hline & i. Able to think logically & 4 & 80 & 5 & 100 \\
\hline & j. Able to think idealistically & 5 & 100 & 5 & 100 \\
\hline & k. Able to solve the problem & 4 & 80 & 5 & 100 \\
\hline & 1. Improved linguistic ability & 4 & 80 & 5 & 100 \\
\hline & m. Mastering special linguistic term (slang language) & 5 & 100 & 5 & 100 \\
\hline & Average & 4.23 & 84.61 & 4.92 & 98.46 \\
\hline \multirow[t]{9}{*}{3} & Moral \& Spiritual Aspect & & & & \\
\hline & a. Understand the ethical value, religious and social norms. & 4 & 80 & 5 & 100 \\
\hline & b. Care on others' need & 4 & 80 & 5 & 100 \\
\hline & c. Have a good manner toward parents and teachers & 5 & 100 & 5 & 100 \\
\hline & d. Good to friends & 4 & 80 & 5 & 100 \\
\hline & e. Start to obey the rule in society & 5 & 100 & 5 & 100 \\
\hline & f. Diligently do the religious practice & 4 & 80 & 5 & 100 \\
\hline & g. Enjoining good and forbidding wrong & 4 & 80 & 5 & 100 \\
\hline & Average & 4.28 & 85.71 & 5 & 100 \\
\hline
\end{tabular}




\begin{tabular}{lccc}
\hline No & Adolescence Change & Pre & Post \\
\cline { 2 - 4 } & & $\begin{array}{c}\text { Number } \\
\text { of clients }\end{array}$ & $\begin{array}{c}\text { Number } \\
\text { of clients }\end{array}$ \\
\hline
\end{tabular}

$4 \quad$ Emotional \& psychosocial aspect

\begin{tabular}{lcccc} 
a. Able to not forcing the parents to follow their demand & 3 & 60 & 5 & 100 \\
b. Able to control themselves & 5 & 100 & 5 & 100 \\
c. Emotionally stable & 4 & 80 & 5 & 100 \\
d. Able to adapt to the environment & 4 & 80 & 5 & 100 \\
e. Give concern to other & 4 & 80 & 4 & 80 \\
f. Get achievement $\quad$ Average & 5 & 100 & 5 & 100 \\
\hline Talent \& creativity aspect & 4.16 & 83.33 & 4.83 & 96.66 \\
\hline a. own the improving special talent & 3 & 50 & 5 \\
b. follow extra activities & 3 & 60 & 5 & 100 \\
c. critical & 3 & 60 & 4 & 80 \\
d. curious & 4 & 80 & 5 & 100 \\
e. able to deliver opinion and question & 3 & 60 & 4 & 80 \\
f. interested in the new experience & 4 & 80 & 5 & 100 \\
g. interested in challenging & 3 & 60 & 5 & 100 \\
\hline Average & 3.28 & 65.71 & 4.71 & 94.28 \\
\hline
\end{tabular}

Table 2.

Case Description

\begin{tabular}{lr}
\hline Client's & Case Description \\
Initial &
\end{tabular}

Ms.S Female, 14 years old, second grade of junior high school, parents are labors whose income below the provincial minimum wage, having 5 siblings. Ms. S is healthy, without any serious disease history, normal eating pattern, the weight gain in accordance to the development, client is able to deliver her opinion, able to critically speak about problem, able to differentiate which is good and bad, loves to try new thing, has many friends, able to adapt in the new environment, extrovert, cheerful, involve in some social activities.

Ms. N Female, 17 years old, first grade of vocational high school, parents are entrepreneurs whose income above the provincial minimum wage, has 1 sibling. Ms. $\mathrm{N}$ is healthy, without any serious disease history, normal eating pattern, the weight gain in accordance to the development, client is able to deliver her opinion, able to critically speak about problem, able to differentiate which is good and bad, loves to try new thing, has many friends, diligently does the prayers, active in school organization activities, able to adapt in the new environment, extrovert, cheerful, involve in some social activities. The client has had a conflict with the peer around her school and house environment.

Ms. Y Female, 18 years old, the third grade of vocational high school, parents are whose income below the provincial minimum wage, having 3 siblings. Ms. Y is healthy, without any serious disease history, normal eating pattern, the weight gain in accordance to the development, client is able to deliver her opinion, able to critically speak about problem, able to differentiate which is good and bad, loves to try new thing, has many friends, diligently does the prayers, active in school organization activities, able to adapt in the new environment, extrovert, cheerful, involve in some social activities. There is a history of chronic disease in the client's family. The aunt and father of Ms. Y suffered from hypertension. Ms. Y had been hospitalized when she was 10 (varicella) and 15 (fever, throat problem). The client has an irregular eating pattern with coffee consumption habits since she was 13, at least 1 glass per day.

Mr. S Male, 14 years old, second grade of junior high school, the parent is a driver whose income below the provincial minimum wage, has 2 siblings. The client has gastritis history and had been hospitalized a year ago, smoking since he was 13 , have had alcohol when he was 12 . The client also had a conflict with the peer from school and the house environment. The client rarely does the prayer and never joins the social activities. There is a history of chronic disease in the client's family. The grandfather and mother of the client suffered from hypertension.

Mr. P Male, 15 years old, the third grade of junior high school, his father was a police officer, but then dropped out from the office because of scamming scandal, the father is now jobless with the income below the provincial minimum wage, has 3 siblings. The client has an irregular eating pattern with coffee consumption habits since he was 13, at least 1 glass per day. There is a history of chronic disease in the client's family. The mother of the client suffered from hypertension. The client is an introvert, silent, and rarely joins the social activities. 
Table 3

Ability in self-identity formation pre and post specialist therapy for clients in RW 4 Mulyaharja District

\begin{tabular}{llcc}
\hline \multicolumn{1}{c}{ Self-identity } & & Count & \% \\
\hline Able to objectively assess himself/herself & Pre & 4 & 80 \\
& Post & 5 & 100 \\
& Delta & 20 \\
\hline Able to figure the future & Pre & 3 & 60 \\
& Post & 5 & 100 \\
& Delta & 40 \\
\hline Able to make decision & Pre & 3 & 60 \\
& Post & 5 & 100 \\
& Delta & 40 \\
\hline Love himself/herself & Pre & 60 \\
& Post & 3 & 100 \\
& Delta & 5 & 40 \\
\hline Able to interact with others & Pre & 80 \\
& Post & 4 & 100 \\
& Delta & 5 & 20 \\
\hline Responsible & Pre & 60 \\
& Post & 3 & 80 \\
Independent & Delta & 4 & 20 \\
\hline Able to solve a problem with & the & Pre & 100 \\
assistance & Post & & 100 \\
& Delta & 5 & 0 \\
\hline
\end{tabular}

\section{DISCUSSION}

The case and care management by specialist nurse delivered the therapeutic group therapy and family psychoeducation for 5 adolescence clients who were in the selfidentity formation stage. From the result, it could be seen that all of the aspects of adolescence development were improved. The family was able to take care and facilitate clients, while the clients are able to use the supporting source from the inside and outside the family to deal with health problems.

After therapeutic group therapy, the biological development of clients was improved. On the other hand, from the literature review, there was no study explained the influence of the therapy toward biological development. According to other studies that the optimum stimulus such as maintaining body health, a healthy lifestyle, maintain cleanliness, regular exercise, immediate treatment for illness, and a healthy diet was able to affect the physical and biological development. There was a significant improvement in adolescence psychosexual development after the therapy. In terms of distortion, an adolescent may interact with homosexual activity. The orientation may also be affected by the appearance and gender identity formation. ${ }^{10}$ Based on the other case study on gay adolescents, it was stated that gay adolescents were trapped in gender identity confusion. ${ }^{11}$ In this case, group therapy was able to strengthen and improve adolescents' self-identity. Besides, group therapy also enables adolescents to give positive feedback to others, giving chance to build self-identity and learn from normal people. Gender identity is able to influence sexual orientation. As mentioned by Freud, the normal characteristic of a genital psychosexual stage was within the adolescence stage (12-18 years old). It can be seen from the sexual attraction, 
improved sexual fantasy, and the improved interest in their own appearance according to their gender ${ }^{1}$ The result of the study concluded that psychosexual development was improved in line with the biological development in a form of hormonal change and physical change, especially in the reproductive organs. This way, the therapy needs at least 6 sessions to accomplished.

The ability in cognitive development was not significantly improved before and after the TGT. According to Piaget, the adolescence period is the period where the thinking pattern of an individual changes from the concrete to formal operational. The formal operational thinking involves the ability to think abstractly, think hypothetically, able to use future perspective, able to figure out the possibilities and consequences from things happened, and the development of the ability in making the decision. Able to relate an idea, thinking or concept, analyze and solve the problem, start to think ideally, logically, and systematically to solve the problem. ${ }^{9}$ The cognitive development was not improved as to achieve cognitive development require more abstract thinking training. During the cognitive stimulation session, the researcher only applied two sessions of therapy which involved the explanation about cognitive ability should be accomplished by adolescents and also the game to stimulate thinking ability, asking ability, and problemsolving ability. And then, during the linguistic development stage, there was a significant improvement after the therapeutic group therapy intervention. Referred to the result of other research was expected that the entire individual has learned about all the linguistic and performance skill to well understand and produce certain language when they enter the adolescence period. ${ }^{12}$ The linguistic development was supported by the operational formal cognitive ability. Cognitive development definitely improves linguistic ability. The correlation between development and self-identity was that self- identity came from self-assessment and observation. The combination of the developments from all of the aspects of the development formed the characteristic of an individual that differentiates one to another. An adolescent who has accomplished the formal operational development is able to think logically, make the hypothesis, imagine his or her future identity, and able to solve the problem. ${ }^{13}$ The problem in linguistic development may involve the difficulty in delivering the opinion, the unsystematic sentence, and the inability to understand some words in their own language. It is possible as linguistic ability requires the intensive and comprehensive process, despite the fact that adolescents commonly have been trained to speak, delivered the opinion, and asked the question.

The ability to moral development was improved after the application of therapeutic group therapy. The result of the research was not in line with other studies which concluded that the therapeutic group was able to help the member in changing maladaptive attitudes. Ethical value and system was the main instrument to control the impulse during the self-identity formation. During the therapy, the therapist should actively apply positive moral values such as respecting the other group members, presenting a well-mannered attitude, obeying the rule, and applying discipline value. After the therapeutic group therapy, spiritual development was also improved. The adolescents tended to be more interested in religious value, try to apply the value, and stay away from the religious forbid. There was no study examining the influence of group therapy on spiritual development. The moral development can be improved by respecting the noble value, differentiate between good and bad, right and wrong, and also possess a good attitude.

After the therapeutic group therapy, the emotional development of the adolescents was improved. It meant that group therapy 
significantly influenced emotional development such as improving adaptive skills, giving more concern to others, able to control demand and anger. The emotional development would also form an individual character in reacting to a problem. Psychological problems, dynamic psychological state, the complexity of ego defense, and adolescent's character are able to influence self-identity formation. ${ }^{14}$ According to other research that group therapy enables adolescents to express emotion and behavioral problems, give feedback on the annoying behavior of others, learn how to tolerate, and give chance to practice new behavior. ${ }^{15}$ In group therapy, adolescents are able to learn how to care and love each other, and how to restrain temperament. The group therapy was given to adolescents for two weeks to show a significant result to restrain anger in adolescents. There was also an improvement in the psychosocial development of adolescents. The result of this nursing care was in line with the conclusion of other research which stated that group therapy builds a healthy relationship, especially with the opposite sex. ${ }^{16}$ It will further stimulate future realization, create balance in the family, build openness, productivity, love, and able to avoid conflict, confrontation, and also temperamental behavior in the family. The group intervention was proven to be effective for adolescents since adolescents are easier to accept the peer's opinion more than the adult's opinion. It is the opinion which usually emphasizes on the importance of relationship, the importance of group's norms for the socialization, the cooperation between group members, and the group which is able to listen very well.

There was an improvement in talent and creativity development after therapeutic group therapy. According to other research that talent can be trained to be a special skill in a certain area. In order to dose, training, knowledge, experience, and motivation are needed. ${ }^{17}$ During the sixth session of the therapy, the researcher has given the talent stimulation by giving the knowledge about the importance of talent and also giving the chance to show some talents such as singing, poetry, storytelling, including how to give the reward for the performance. The only problem was not all of the clients agreed to perform in front of others. Some of them also have the talent of which impossible to be demonstrated in that session, such as swimming, playing football, and playing badminton.

\section{CONCLUSION}

Most of the clients for the therapeutic group therapy were from early and mid-stage of adolescence, mostly females, mostly the first children in the family with two or three siblings. All of the adolescents in the group went through positive improvement and skill. The ability of family for the selfidentity formation was also improved. All of the mothers had been used the available health care. The therapeutic group therapy was applied within the 10 aspects of adolescence stages (biological, psychosexual, cognitive, language, moral, spiritual, emotional, psychosocial, talent, and creativity). The interpersonal model by Peplau, Erickson, and Stuart were suitable for the adolescents. It was possible since the stages of the interpersonal relationship involved orientation, identification, exploitation, and resolution stages were applicable for the adolescence and enable the students to easily apply the nursing care.

\section{ACKNOWLEDGMENTS}

Thank you to all of the informan and those who have helped this case study.

\section{CONFLICTS OF INTEREST}

Neither of the authors has any conflicts of interest that would bias the findings presented here. 


\section{REFERENCES}

1. Stuart, G.W\&Laria M. Principles and Practiv of Psychiatric Nursing. In: 8th ed. St Louis: Mosby; 2009.

2. WHO. Mental Health Atlas 2014.

3. Potter PAG. Fundamental of Nursing. Vol volume 1. Edisi 7. Jakarta: Salemba Medika; 2009.

4. Alligood MR. Nursing Theory and their work (8thed). In: Elsevier. Philadelphia: Elsevier; 2017.

5. Varcarolis \& Halter. Foundation of Psychiatric Mental Health Nursing a Clinical approach 6th Ed. In: Elsevier. Canada: Elsevier; 2010.

6. Keliat, Akemat., Daulima, N. H. C., \& Nurhaeni H. Keperawatan Kesehatan Jiwa Komunitas: CMHN Basic Course. In: Jakarta: EGC; 2011.

7. Jannah. Pengaruh Terapi Geeneralis Latihan Keterampilan Sosial Terhadap Pencapaian Identitas Diri Remaja Panti Asuhan Di Kabupaten Banyumas. Unpubl thesis. 2012.

8. Trihadi. dkk. Pengruh terapi kelompok terapeutik terhadap kemampuan keluarga dalam memberikan stimulasi perkmbangan kanak-kanak dikelurahan bubulak kota bogor. Unpubl thesis. 2009.

9. Bahari. Pengaruh terapi kelompok terapeutik terhadap perkembangan identitas diri remaja di kota malang. In: Jakarta: Nursing Department of Univeristy of Indonesia.; 2010.

10. Kumrun, A. \& Thompson R. Ego Identity Status and Self-Monitoring Behavior In Adolescents. Adolesc Res. 2003:1-16.

11. Ali,M\&Ansori M. Psikologi remaja perkembangan peserta didik. In: 6th ed. Jakarta: PT Bumi Aksara; 2010.

12. Hasanah. Pengaruh terapi kelompok terapeutik remaja dan psikoedukasi keluarga terhadap perkembangan identitas diri remaja. Keperawatan. 2017;9 No 1:13-23.

13. Grnholm, E. et al. Group Cognitive-behavioral Social Skills Training For Older outpatients with Chonic Schizophrenia. J Cogn Psychoter $n$ Int Q. 2006;18(3):265-279.

14. Lench H. Anger manageement: Diagnostic difference and treatment Implication. J Soc Clin Psychol. 2014;23(4):512-531.

15. Puspitasari, D. L., Mubin, M. F. \&Targunawan. Gambaran Psikologis: Konsep Diri pada Anak Remaja di Wilayah Banjir Rob. JurnalI Imu Keperawatan dan Kebidanan. 2014.

16. Maryatun. Pengaruh Terapi Kelompok Terapeutik Terhadap Perkembangan Di Panti Sosial Marsudi Putra Dharma pala Ideralaya. Keperawatan Sriwij. 2014;1(1).

17. Purwadi. Hubungan Gaya Pengasuhan Orang Tua Denagan Eksplorasi Dan Komitmen Remaja Dalam Domain Pekerjaan. 2004. 